Table 1. Number of Patients with AEs per 100 PY and Incidence of AEs of Interest

\begin{tabular}{|c|c|c|c|c|c|c|c|c|}
\hline \multirow{3}{*}{$\begin{array}{l}\text { Time Period } \\
\text { Treatment Group } \\
\text { Dosing Schedule }\end{array}$} & \multicolumn{4}{|c|}{24 Weeks } & \multicolumn{4}{|c|}{1 Year* } \\
\hline & \multirow{2}{*}{$\begin{array}{c}\text { PBO } \\
\text { Matching }\end{array}$} & \multicolumn{3}{|c|}{ GUS SC $100 \mathrm{mg}$} & \multirow{2}{*}{$\frac{\text { PBO to GUS }^{\ddagger}}{q 4 w}$} & \multicolumn{3}{|c|}{ GUS SC $100 \mathrm{mg}$} \\
\hline & & q8w & $q 4 w$ & $\begin{array}{c}\text { GUS } \\
\text { Combined }^{\dagger}\end{array}$ & & q8w & $q 4 w$ & $\begin{array}{c}\text { GUS } \\
\text { Combined }^{\ddagger}\end{array}$ \\
\hline $\mathrm{N}$ & 372 & 375 & 373 & 748 & 352 & 375 & 373 & 1100 \\
\hline Total PY Follow-Up & 173 & 173 & 172 & 346 & 204 & 384 & 385 & 589 \\
\hline \multicolumn{9}{|c|}{ Patients with AEs per $100 \mathrm{PY}, \mathrm{n}(95 \% \mathrm{Cl})$} \\
\hline$\geq 1 \mathrm{AE}$ & $143(123,166)$ & $148(127,171)$ & $154(132,178)$ & $151(136,167)$ & $92(77,108)$ & $114(100,130)$ & $115(101,131)$ & $109(100,117)$ \\
\hline$\geq 1$ Serious $\mathrm{AE}$ & $7.1(3.7,12)$ & $4.1(1.6,8.4)$ & $4.7(2.0,9.3)$ & $4.4(2.5,7.3)$ & $7.0(3.8,11.8)$ & $4.8(2.9,7.6)$ & $4.0(2.2,6.6)$ & $4.9(3.6,6.6)$ \\
\hline$\geq 1$ Infection & $50(39,62)$ & $47(37,59)$ & $52(42,65)$ & $49(42,58)$ & $39(31,49)$ & $41(34,48)$ & $38(31,45)$ & $39(35,44)$ \\
\hline$\geq 1$ Serious Infection & $1.7(0.4,5.1)$ & $0.6(0.0,3.2)$ & $1.8(0.4,5.1)$ & $1.2(0.3,3.0)$ & $2.5(0.8,5.8)$ & $1.3(0.4,3.1)$ & $0.8(0.2,2.3)$ & $1.3(0.7,2.3)$ \\
\hline Discontinued due to $\mathrm{AE}$ & $4.1(1.6,8.4)$ & $2.9(1.0,6.8)$ & $4.7(2.0,9.3)$ & $3.8(2.0,6.5)$ & $3.5(1.4,7.1)$ & $2.1(0.9,4.1)$ & $2.6(1.3,4.8)$ & $2.6(1.7,3.8)$ \\
\hline \multicolumn{9}{|l|}{ AEs of Interest ${ }^{\S}, n(\%)$} \\
\hline Death & $2(0.5)$ & 0 & 0 & 0 & 0 & 0 & 0 & 0 \\
\hline Malignancy & $1(0.3)$ & $2(0.5)$ & 0 & $2(0.3)$ & $1(0.3)$ & $2(0.5)$ & 0 & $3(0.3)$ \\
\hline Major Adverse Cardiac Events & $1(0.3)$ & 0 & $1(0.3)$ & $1(0.1)$ & 0 & 0 & $1(0.3)$ & $1(0.1)$ \\
\hline Opportunistic Infections & 0 & 0 & 0 & 0 & 0 & 0 & 0 & 0 \\
\hline Tuberculosis & 0 & 0 & 0 & 0 & 0 & 0 & 0 & 0 \\
\hline Inflammatory Bowel Disease & $1(0.3)$ & 0 & 0 & 0 & 0 & 0 & 0 & 0 \\
\hline Injection-Site Reaction & $1(0.3)$ & $5(1.3)$ & $4(1.1)$ & $9(1.2)$ & $4(1.1)$ & $6(1.6)$ & $9(2.4)$ & $19(1.7)$ \\
\hline Anti-GUS Antibody ${ }^{+}$ & - & $6 / 373(1.6)$ & 9/371 (2.4) & $15 / 744(2.0)$ & $14 / 350(4.0)$ & $18 / 373(4.8)$ & $17 / 371(4.6)$ & $49 / 1094(4.5)$ \\
\hline
\end{tabular}

${ }^{\star}$ Through w60 for DISCOVER 1 and w52 for DISCOVER 2; ${ }^{\dagger}$ Combined GUS q8w and q4w; ${ }^{\ddagger}$ For patients who switched from PBO to GUS, only data on and after first GUS administration were included in this group; ${ }^{\text {} P B O ~ N}=370 . A E$, adverse event; $\mathrm{Cl}$, confidence interval; GUS, guselkumab; PBO, placebo; PY, patient year; q4w, every 4 weeks; q8w, every 8 weeks; SC, subcutaneous; w, week

Methods: Adults with active PSA (DISCOVER 1: $\geq 3$ tender/swollen joints and C-Reactive protein [CRP] $\geq 0.3 \mathrm{mg} / \mathrm{dL}$; DISCOVER $2: \geq 5$ tender/swollen joints and $\mathrm{CRP} \geq 0.6 \mathrm{mg} / \mathrm{dL}$ ) were randomized to subcutaneous GUS $100 \mathrm{mg}$ at $\mathrm{w0}$, w4, then every 8 w (q8w); GUS $100 \mathrm{mg} \mathrm{q4w;} \mathrm{or} \mathrm{PBO.} \mathrm{At} \mathrm{w24,} \mathrm{PBO} \mathrm{pts} \mathrm{switched} \mathrm{to} \mathrm{GUS}$ $100 \mathrm{mg} \mathrm{q} 4 \mathrm{w}$. Pts were biologic naive except $~ 30 \%$ pts in DISCOVER 1. Safety was reported through w60 in DISCOVER 1 and through w52 in DISCOVER 2.

Results: Baseline characteristics were similar between treatment groups in the pooled studies. Through w24 and 1 year, numbers of pts per 100 patient years with $\geq 1$ event were similar among treatment groups for adverse events (AEs), serious AEs, infections, serious infections, and discontinuations due to AE (Table 1). At 1 year, there were no cases of active tuberculosis, opportunistic infections (including candida), or inflammatory bowel disease in GUS-treated pts; 2 deaths in PBO pts; and low incidences that were similar across treatment groups for malignancy, major adverse cardiac events, and injection-site reactions. Incidence of anti-GUS antibodies was $4.5 \%$, and most were not neutralizing. Mild elevations in serum hepatic transaminases and decreases in neutrophil counts were consistent at 1 year with the results at w24 (Table 1).

Conclusion: GUS regimens of $\mathrm{q} 8 \mathrm{w}$ and $\mathrm{q} 4 \mathrm{w}$ were well tolerated in PsA pts through 1 year of treatment in the phase-3 DISCOVER trials, consistent with the w24 results. No meaningful differences between incidences of AEs were reported in the q8w and q4w groups. The safety profile of GUS in PSA pts is generally comparable with the previously established safety profile of GUS. REFERENCES:

[1] Deodhar A et al. Lancet. 2020;395:1115

[2] Mease P et al. Lancet. 2020;395:1126

[3] Ritchlin C et al. EULAR 2020 \# SAT0397

[4] McInnes I et al. EULAR 2020 \# SAT0402

Disclosure of Interests: Christopher T. Ritchlin Grant/research support from: Received grant/research support from UCB Pharma, AbbVie, Amgen, consultation fees from UCB Pharma, Amgen, AbbVie, Lilly, Pfizer, Novartis, Gilead, Janssen, Proton Rahman Speakers bureau: Received speakers fees from Abbott, AbbVie, Amgen, BMS, Celgene, Lilly, Janssen, Novartis, Pfizer, Grant/research support from: Received grant/research support from Janssen and Novartis, consultation fees from Abbott, AbbVie, Amgen, BMS, Celgene, Lilly, Janssen, Novartis, and Pfizer., Philip Helliwell Consultant of: Consultation fees paid to charity (AbbVie, Amgen, Pfizer, UCB) or himself (Celgene, Galapagos), Grant/research support from: Received grants/research support paid to charity (AbbVie, Janssen, Novartis), Wolf-Henning Boehncke Consultant of: Received consultation fees from Janssen, Grant/research support from: Received grant/research support from Janssen Research \& Development, LLC, lain McInnes Consultant of: Received consultation fees from AbbVie, Bristol-Myers Squibb, Celgene, Eli Lilly and Company, Gilead, Janssen, Novartis, Pfizer, and UCB, Grant/research support from: Received grant/research support from Bristol-Myers Squibb, Celgene, Eli Lilly and Company, Janssen, and UCB, Alice B Gottlieb Speakers bureau: Received speakers fees from Pfizer, AbbVie, BMS, Lilly, MSD, Novartis, Roche, Sanofi, Sandoz, Nordic, Celltrion and UCB, Consultant of: Received consultation fees from Pfizer, AbbVie, BMS, Lilly, MSD, Novartis, Roche, Sanofi, Sandoz, Nordic, Celltrion and UCB, Grant/research support from: Received grant/research support from Pfizer, AbbVie, BMS, Lilly, MSD, Novartis, Roche, Sanofi, Sandoz, Nordic, Celltrion and UCB, Shelly Kafka Shareholder of: Shareholder of Johnson \& Johnson, Employee of: Employee of Janssen Research \& Development, LLC, Alexa Kollmeier Shareholder of: Shareholder of Johnson \& Johnson, Employee of: Employee of Janssen
Research \& Development, LLC, Elizabeth C Hsia Shareholder of: Shareholder of Johnson \& Johnson, Employee of: Employee of Janssen Research \& Development, LLC, Xie L Xu Shareholder of: Shareholder of Johnson \& Johnson, Employee of: Employee of Janssen Research \& Development, LLC, May Shawi Shareholder of: Shareholder of Johnson \& Johnson, Employee of: Employee of Janssen Research \& Development, LLC, Shihong Sheng Shareholder of: Shareholder of Johnson \& Johnson, Employee of: Employee of Janssen Research \& Development, LLC, Prasheen Agarwal Shareholder of: Shareholder of Johnson \& Johnson, Employee of: Employee of Janssen Research \& Development, LLC, Bei Zhou Shareholder of: Shareholder of Johnson \& Johnson, Employee of: Employee of Janssen Research \& Development, LLC, Paraneedharan Ramachandran Shareholder of: Shareholder of Johnson \& Johnson, Employee of: Employee of Janssen Research \& Development, LLC, Philip J Mease Speakers bureau: Received speakers fees from Abbott, Amgen, Biogen Idec, BMS, Eli Lilly, Genentech, Janssen, Pfizer, UCB - speakers bureau, Consultant of: Received consultation fees from Abbott, Amgen, Biogen Idec, BMS, Celgene Corporation, Eli Lilly, Novartis, Pfizer, Sun Pharmaceutical, UCB, Grant/research support from Received grant/research support from Abbott, Amgen, Biogen Idec, BMS, Celgene Corporation, Eli Lilly, Novartis, Pfizer, Sun Pharmaceutical, UCB. DOI: 10.1136/annrheumdis-2021-eular.1334

\section{AB0539 \\ IXEKIZUMAB TREATMENT RESPONSE: CONSISTENCY OVER TIME AND AT EACH VISIT IN PSORIATIC ARTHRITIS}

L. C. Coates ${ }^{1}$, D. Sandoval' ${ }^{2}$ R. Bolce ${ }^{2}$, C.Y. Lin $^{2}$, K. Stenger ${ }^{2}$, A. T. Sprabery²,

A. Kavanaugh ${ }^{3}{ }^{1}$ Oxford University, Nuffield Department of Orthopaedics,

Rheumatology and Musculoskeletal Sciences, London, United Kingdom; ${ }^{2}$ Eli Lilly and Company, Lilly Corporate Center, Indianapolis, United States of America; ${ }^{3}$ UC San Diego, School of Medicine, San Diego, United States of America

Background: Ixekizumab (IXE), a high-affinity monoclonal antibody targeting IL-17A, has demonstrated superiority in achieving the combined endpoint of ACR50 and PASI100 at week (Wk) 24 compared to adalimumab (ADA) in the SPIRIT-H2H trial [1]. In this analysis, we looked at the efficacy responses at the individual patient (pt) level to assess consistency over time and at each visit.

Objectives: To determine the American College of Rheumatology $50 \%$ (ACR50) response and Disease Activity in psoriatic arthritis (PsA) (DAPSA) response in pts treated with IXE and describe response consistency over time and at each visit from Wk 24 through Wk 52.

Methods: This post-hoc analysis used data from SPIRIT-H2H (NCT03151551), a phase $3 \mathrm{~b} / 4$ randomised, open-label parallel-group study between IXE and ADA. Pts were randomised to receive either IXE $80 \mathrm{mg}$, every 4 Wks (IXE Q4W)) or ADA $40 \mathrm{mg}$, every 2 Wks (ADA Q2W)). The proportion (\%) of pts in the intent-to-treat population who achieved each endpoint, either ACR50 or DAPSA $\leq 14$, at Wk 24 and at each post-baseline visit out to Wk 52 was assessed. Nine pts with active psoriasis and body surface area (BSA) $\geq 3 \%$ were assessed as PASI $=0$ at baseline, a medical inconsistency that was resolved using medical judgement. These pts were considered PASI 100 responders if $\mathrm{PASI}=0$ and $\mathrm{BSA}=0$ at post baseline visits. Results: A total of 566 patients enrolled in the trial received either IXE (N=283) or ADA $(\mathrm{N}=283)$. Of the $143 \mathrm{pts}$ treated with IXE who achieved ACR50 at Wk 24, 65\% (N=93) maintained ACR50 at every visit. In total, $83 \%(\mathrm{~N}=118)$ of the $A C R 50$ achievers at Wk 24 maintained ACR50 with some (18\% ( $\mathrm{N}=25))$ fluctuations, between ACR50 and 
ACR20 (Figure 1). Of the 132 pts treated with ADA who achieved ACR50 at Wk 24, $55 \%(\mathrm{~N}=72)$ maintained ACR50 at every visit. In total, $80 \%(\mathrm{~N}=105)$ of ACR50 achievers maintained ACR50 with some $(25 \%(\mathrm{~N}=33))$ fluctuations between ACR50 and ACR20 (Table 1). Furthermore, of the174 pts treated with IXE who achieved low DA (DAPSA $\leq 14)$ at $W k 24,68 \%(\mathrm{~N}=119)$ maintained low DA at every visit. Of the low DA achievers at Wk $24,82 \%(\mathrm{~N}=142)$ of pts maintained low DA with some $(13 \%(\mathrm{~N}=23))$ fluctuations between moderate and low DA (Figure 1B). Of the 171 pts treated with ADA who achieved low DA at Wk $24 ; 57 \%(\mathrm{~N}=97)$ maintained low DA at every visit. In total, $77 \%(\mathrm{~N}=131)$ of low DA achievers at Wk 24 maintained low DA with some $(20 \%$ $(\mathrm{N}=34)$ ) fluctuations between moderate and low DA (Table 1).

Conclusion: This analysis demonstrates that a numerically higher proportion of pts treated with IXE versus ADA show consistency of response, as measured by ACR50 and DAPSA responses, over time and for each visit at the pt level. REFERENCES:

[1] Mease et al. Ann Rheum Dis. 2020;79(1):123-131

Table 1. Consistency over time of the effect of ADA in pts with PsA.

\begin{tabular}{|c|c|c|c|c|}
\hline & \multicolumn{2}{|c|}{$\begin{array}{l}\text { IXE Q4W } \\
(\mathrm{N}=283)\end{array}$} & \multicolumn{2}{|c|}{$\begin{array}{c}\text { ADA Q2W } \\
(\mathrm{N}=283)\end{array}$} \\
\hline & $\begin{array}{l}\text { ACR50 } \\
\text { Response, } \\
\%(n)\end{array}$ & $\begin{array}{l}\text { DAPSA } \leq 14 \\
\text { low DA } \\
\%(n)\end{array}$ & $\begin{array}{l}\text { ACR50 } \\
\text { Response, } \\
\%(n)\end{array}$ & $\begin{array}{c}\text { DAPSA } \leq 14 \\
\text { Iow DA, } \\
\%(n)\end{array}$ \\
\hline $\begin{array}{l}\text { Patients who achieved the } \\
\text { response at Wk } 24\end{array}$ & $51 \%(143)$ & $61 \%(174)$ & $47 \%(132)$ & $60 \%(171)$ \\
\hline $\begin{array}{l}\text { Achieved endpoint at Wk } \\
24 \text { and maintained out } \\
\text { to Wk } 52 \text { with some } \\
\text { fluctuations* }\end{array}$ & $83 \%(\mathrm{~N}=118)$ & $82 \%(\mathrm{~N}=142)$ & $80 \%(105)$ & $77 \%(131)$ \\
\hline $\begin{array}{l}\text { Maintained endpoint at } \\
\text { every visit }\end{array}$ & $65 \%(\mathrm{~N}=93)$ & $68 \%(\mathrm{~N}=119)$ & $55 \%(72)$ & $57 \%(97)$ \\
\hline Had some fluctuations* & $18 \%(N=25)$ & $13 \%(\mathrm{~N}=23)$ & $25 \%(33)$ & $20 \%(34)$ \\
\hline
\end{tabular}

* fluctuations between ACR50 and ACR20, or between low and moderate disease activity.

\section{DAPSA $\leq 14$ LDA}

\section{IXEQ4W (N=174)}

Week

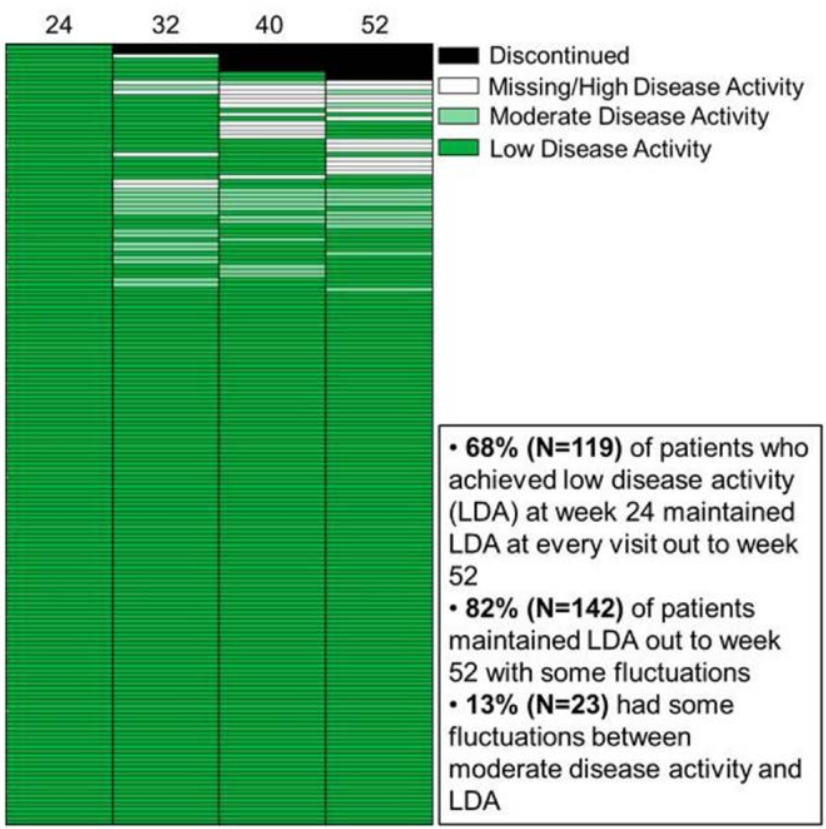

Figure 1. Heatmap diagram describing consistency over time of the effect of IXE in pts with PsA who achieved DAPSA $\leq 14$ (low disease activity) at Wk 24

Acknowledgements : Edel Hughes, an employee of Eli Lilly and Company, provided editorial and writing support.

Disclosure of Interests: Laura C Coates Speakers bureau: AbbVie, Amgen, Biogen, Celgene, Gilead, Eli Lilly, Janssen, Medac, Novartis, Pfizer, and UCB., Consultant of: AbbVie, Amgen, Boehringer Ingelheim, Bristol-Myers Squibb, Celgene, Eli Lilly, Gilead, Janssen, Novartis, Pfizer, and UCB, Grant/research support from: AbbVie, Amgen,
Celgene, Eli Lilly, Pfizer, and Novartis, David Sandoval Shareholder of: Eli Lilly \& Company, Employee of: Eli Lilly \& Company, Rebecca Bolce Shareholder of: Eli Lilly \& Company, Employee of: Eli Lilly \& Company, Chen-Yen Lin Shareholder of: Eli Lilly \& Company, Employee of: Eli Lilly \& Company, Keri Stenger Shareholder of: Eli Lilly \& Company, Employee of: Eli Lilly \& Company, Aubrey Trevelin Sprabery Shareholder of: Eli Lilly and Company; Johnson and Johnson, Employee of: Eli Lilly and Company, Arthur Kavanaugh Consultant of: AbbVie, Amgen, Eli Lilly, BMS, Pfizer, Novartis, Janssen.

DOI: 10.1136/annrheumdis-2021-eular.1514

\section{AB0540 COMPARISON OF EQ-5D HEALTH STATUS IN PSORIATIC ARTHRITIS PATIENTS WITH OR WITHOUT AXIAL DISEASE: RESULTS OF SUBANALYSIS OF THE PATERA STUDY}

1. Gaydukova ${ }^{1}$, T. Korotaeva ${ }^{2}$, V. Mazurov ${ }^{1}$, A. Samtsov ${ }^{3}$, V. Khayrutdinov ${ }^{3}$, A. Bakulev ${ }^{4}$, A. Kundzer ${ }^{5}$, N. Soroka ${ }^{6}$, A. Eremeeva ${ }^{7}{ }^{1}$ Mechnikov NorthWestern State Medical University, Department of Therapy and Rheumatology of Temporary Disability and Medical Care Quality Expertise, St-Petersburg, Russian Federation; ${ }^{2}$ Nasonova Research Institute of Rheumatology, Laboratory of Spondyloarthritides and Psoriatic Arthritis, Moscow, Russian Federation; ${ }^{3}$ Kirov Military Medical Academy, Department of Skin and Veneral Diseases, St-Petersburg, Russian Federation; ${ }^{4}$ Razumovsky Saratov State Medical University, Department of Dermatovenereology and Cosmetology, Saratov, Russian Federation; ${ }^{5}$ Belarusian Medical Academy of Postgraduate Education, Department of Cardiology and Rheumatology, Minsk, Belarus; ${ }^{6}$ Belarusian State Medical University, Department of Internal Diseases №2, Minsk, Belarus; ${ }^{7}$ JSC BIOCAD, Clinical Development Department, St-Petersburg, Russian Federation

Background: Netakimab (NTK) is an anti-interleukin-17A monoclonal antibody approved for psoriasis, ankylosing spondylitis, psoriatic arthritis (PsA) in Russia and Belarus. PATERA is an ongoing phase 3 international double-blind, placebo-controlled clinical study of NTK in PSA (NCT03598751).

Objectives: A subanalysis was performed to assess the effect of NTK on domains of the 5-level EuroQol 5 Dimensions questionnaire (EQ-5D-5L) in patients with inflammatory back pain (IBP) $(\operatorname{IBP}(+))$ and without $(\operatorname{IBP}(-))$ at baseline according to self-reported ASAS IBP criteria, 2009.

Methods: 194 adult patients with PsA (CASPAR criteria, 2006) with inadequate response to csDMARD or one TNFi, were randomly assigned to receive NTK $120 \mathrm{mg}$ or placebo at weeks $0,1,2,4,6,8,10,14,18,22$. The proportion of patients reported $>1$ problem in each domain was evaluated. Patients with missing values were considered as non-responders in the analysis.

Results: 97 PsA patients $(\mathrm{N}=54 \mathrm{IBP}(+), \mathrm{N}=43 \mathrm{IBP}(-))$ received NTK. The subpopulations didn't differ significantly in gender, age, and PsA activity at baseline. Comparable percentage of patients reported any problems for each domain at baseline $(p \geq 0.05)$ (data not shown). IBP(-) subpopulation had a greater improvement for all domains except of anxiety/depression. The absolute declines for $\operatorname{IBP}(+)$ vs $\operatorname{IBP}(-)$ patients were as followed: $24.1 \%$ vs $41.9 \%$ (mobility), 18.5 vs $41.9 \%$ (self-care), $24.0 \%$ vs $51.1 \%$ (usual activities), $24.1 \%$ vs $37.2 \%$ (pain/ discomfort), 33.3\% vs 9.3\% (anxiety/depression). However, the only significan difference between $\operatorname{IBP}(+)$ and $\operatorname{IBP}(-)$ was observed in usual activity (Figure 1). Conclusion: NTK resulted in the growing improvement of each EQ-5D-5L domain through 24 weeks irrespectively of the presence of IBP. IBP(-) subjects showed trend to greater benefit compared to $\operatorname{IBP}(+)$

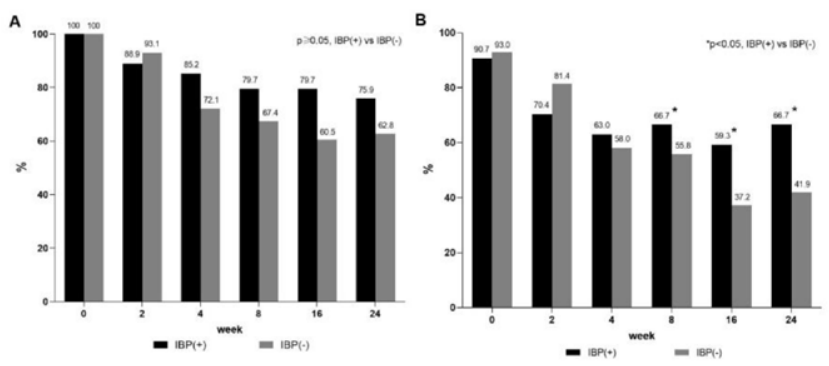

Figure 1 Percentage of patients reported any problems in (A) pain/discomfort, $(B)$ in usual activity at each visit

Acknowledgements: This study was sponsored by JSC BIOCAD.

Disclosure of Interests: Inna Gaydukova Speakers bureau: Abbvie, Biocad, Eli Lilly, MSD, Novartis, Pfizer, Sandoz, Tatiana Korotaeva Speakers bureau: Abbvie, Biocad, Eli Lilly, Johnson \& Johnson, Janssen, Novartis, Pfizer, UCB, V Mazurov: None declared., Aleksey Samtsov: None declared., Vladislav Khayrutdinov: None declared., Andrey Bakulev: None declared., Alena Kundzer: None declared., Nikolaj Soroka: None declared., Anna Eremeeva Employee of: Biocad. DOI: 10.1136/annrheumdis-2021-eular.1535 